\title{
Cloning and characterization of PSF, a novel pre-mRNA splicing factor
}

\author{
James G. Patton, ${ }^{1}$ Elena B. Porro, Joan Galceran, Paul Tempst, ${ }^{2}$ and Bernardo Nadal-Ginard \\ Howard Hughes Medical Institute, Laboratory of Molecular and Cellular Cardiology, Department of Cardiology, Children's \\ Hospital, Department of Molecular and Cellular Physiology, Harvard Medical School, Boston, Massachusetts 02115 USA
}

Previously, we characterized cDNAs encoding polypyrimidine tract-binding protein (PTB) and showed that a complex between PTB and a 100-kD protein was necessary for pre-mRNA splicing. In this paper we have used two different in vitro-binding assays to confirm and extend the interaction between these two proteins.

Peptide sequence information was used to clone and sequence cDNAs encoding alternatively spliced forms of the 100-kD protein. It contains two consensus RNA-binding domains and an unusual amino terminus rich in proline and glutamine residues. The protein is highly basic and migrates anomalously on SDS gels. Owing to its interaction with PTB and its role in pre-mRNA splicing, we have termed the 100-kD protein PTB-associated splicing factor (PSF). The RNA-binding properties of PSF are apparently identical to those of PTB. Both proteins, together and independently, bind the polypyrimidine tract of mammalian introns. Biochemical complementation, antibody inhibition, and immunodepletion experiments demonstrate that PSF is an essential pre-mRNA splicing factor required early in spliceosome formation. Bacterially synthesized PSF is able to complement immunodepleted extracts and restore splicing activity. Despite association with PSF, complementary experiments with antibodies against PTB do not suggest an essential role for PTB in pre-mRNA splicing.

[Key Words: Pre-mRNA splicing; polypyrimidine tract-binding protein; PTB-associated splicing factor; cloning] Received December 9, 1992; revised version accepted January 5, 1993.

The removal of intervening sequences from pre-mRNAs requires the formation of splicing complexes in an ordered, ATP-dependent pathway (for reviews, see Sharp 1987; Krainer and Maniatis 1988; Steitz et al. 1988; Smith et al. 1989a, Green 1991; Guthrie 1991). The assembly of multiple factors into these spliceosomes leads to intron excision through a two-step cleavage-ligation reaction. The development of mammalian in vitro splicing systems has allowed the identification of several cisand trans-acting components necessary for pre-mRNA splicing. Chief among the required cis-acting elements are a consensus sequence at the $5^{\prime}$ splice site, a branchpoint sequence and adjacent polypyrimidine tract, and the $3^{\prime}$ splice site AG dinucleotide (Mount 1982; Ohshima and Gotoh 1987). Among the best characterized of the trans-acting factors are the family of small nuclear ribonucleoprotein particles, the U snRNPs (Steitz et al. 1988). U1 and U2 snRNP initially base-pair with the $5^{\prime}$ splice site and the branchpoint sequence, respectively, followed by the joining of U4/U6 and U5 as part of a preformed triple snRNP (Behrens and Lührmann 1991). Before catalysis, multiple base-pairing interactions between the pre-mRNA and small nuclear RNAs (snRNAs)

Present addresses: 'Department of Molecular Biology, Vanderbilt University, Nashville, Tennessee 37235 USA; ${ }^{2}$ Molecular Biology Program, Sloan-Kettering Institute, New York, New York 10021 USA. as well as between different snRNAs, suggest a very dynamic spliceosome (Datta and Weiner 1991; Wu and Manley 1991; Newman and Norman 1992; Reich et al. 1992; Steitz 1992; Wassarman and Steitz 1992). While RNA-RNA interactions likely underlie the transesterification reactions central to pre-mRNA splicing (for review, see Guthrie 1991; Steitz 1992), multiple protein components, both snRNP and non-snRNP, are also required for pre-mRNA splicing. Each snRNP particle consists of one or two small RNAs complexed with common and unique proteins (Lührmann 1988). Additional snRNPs are found associated with multi-snRNP complexes and are likely responsible for their formation (Behrens and Lührmann 1991). Genetic methods in the yeast Saccharomyces cerevisiae have identified many proteins necessary for pre-mRNA splicing, both snRNP and non-snRNP (Ruby and Abelson 1991). However, the number of known mammalian non-snRNP proteins required for splicing remains limited. Of these, U2 auxiliary factor (U2AF; Ruskin et al. 1988; Zamore and Green 1989,1991 ) is necessary for U2 snRNP binding to the branchpoint. Although U2AF contains a functionally important region rich in arginines and serines (Zamore et al. 1992), it is not a member of a family of proteins characterized by the presence of such $\mathrm{R} / \mathrm{S}$ repeats. This $\mathrm{R} / \mathrm{S}$ family of proteins, including ASF/SF2 and SC35 (Fu and Maniatis 1990,1992; Ge and Manley 1990,1991; Krainer 
et al. 1990a,b, 1991; Zahler et al. 1992), can restore splicing activity to normally inactive cytoplasmic S-100 extracts and they can also alter $5^{\prime}$ splice site selection in a concentration-dependent manner. Two additional mammalian proteins of 75 and $88 \mathrm{kD}$ have been purified extensively and shown to be necessary for precomplex formation or splicing, respectively (Ast et al. 1991; Kramer 1992).

Multiple RNA-binding proteins have been identified, many of which bind to the polypyrimidine tract /Gerke and Steitz 1986; Tazi et al. 1986; Swanson and Dreyfuss 1988; Garcia-Blanco et al. 1989|. Antibodies against heterogenous nuclear RNP (hnRNP) C inhibit in vitro splicing, but this inhibition cannot be complemented with purified protein, leaving open to question the exact function of this protein in splicing (Choi et al. 1986). Despite displaying the ability to bind to the 3 ' splice site, hnRNP Al can affect $5^{\prime}$ splice site selection in a concentrationdependent manner acting in opposition to ASF/SF2 (Mayeda and Krainer 1992). However, it is not essential for constitutive splicing (Ben- David et al. 1992). A factor termed DSF also acts in opposition to ASF/SF2 (Harper and Manley 1991) and may be identical to hnRNP A1. Finally, a variety of splicing activities have been described, although their exact protein components or specific functions await further clarification (Krainer and Maniatis 1985; Mayeda et al. 1986; Kramer et al. 1987; Pruzan et al. 1990; Utans and Kramer 1990; Dellannoy and Caruthers 1991; Kramer and Utans 1991; Utans et al. 1992/. Given the estimated number of mammalian spliceosome proteins (Reed 1990; Bennett et al. 1992a) and data about the number of required splicing proteins in yeast, it seems clear that many more mammalian proteins remain to be characterized.

Previously, we reported the cDNA sequence and RNAbinding specificity of polypyrimidine tract-binding protein (PTB; Gil et al. 1991; Patton et al. 1991). In addition, we showed that fractions enriched in PTB could restore splicing activity to biochemically depleted extracts. These fractions contained three major proteins, PTB, hnRNP Al, and a protein that migrates at $100-\mathrm{kD}$. Further fractionation suggested that PTB and the $100-\mathrm{kD}$ protein form a large complex and that this complex was necessary for splicing. However, we were unable to dissect the individual roles played by PTB and the $100-\mathrm{kD}$ protein. Here, we report the cDNA sequence of the 100$\mathrm{kD}$ protein and utilize biochemical complementation and antibody inhibition to show that it is necessary for pre-mRNA splicing. We have termed this protein PSF (PTB-associated Splicing Factor). Using two different binding assays, we show that PTB and PSF directly interact, confirming the complex between the two proteins.

\section{Results}

\section{A PTB/PSF complex complements biochemically depleted splicing extracts}

Previously, we used a biochemical complementation assay to show that fractions enriched in PTB were neces- sary for pre-mRNA splicing (Patton et al. 1991). These fractions contained three major proteins: PSF, PTB, and hnRNP A1 (Fig. 1A, Lane 2). In an effort to further refine the components necessary for splicing activity, we isolated purified PTB (Fig. 1A, lane 3) and a large molecular mass complex consisting of PTB and PSF (Fig. 1A, lane 5 ). These various protein preparations were used to replace the crude UIM fraction in the complementation assay described above and in Figure 1B. Confirming our previous results, all three crude fractions (U500, U1M, and U2AF/ must be recombined for spliced product formation (Fig. 1B). Replacing the U1M fraction with purified PTB produces only small amounts of spliced product. In contrast, replacing the U1M fraction with either poly(U)-purified PTB/PSF (Fig. 1A, lane 2) or gel filtration-purified fractions containing both PSF and PTB (Fig. $1 \mathrm{~A}$, lane 5) yields nearly as much spliced product as is seen using crude fractions. There is no requirement for hnRNP Al in this assay. Because the U500 flowthrough fraction used in these experiments is not completely depleted of PTB or PSF (data not shown), the first step of splicing is able to proceed in the absence of any U1M fraction. However, the addition of fractions containing both PTB and PSF results in a significant increase in the efficiency of both steps of splicing. The minimal rescue observed with purified PTB suggests that PSF alone, or in combination with PTB, is necessary for splicing.

\section{Cloning of PSF CDNAs}

To further investigate the individual role of PSF, we sought to obtain cDNA clones encoding this protein. Filter-bound protein was digested with trypsin, and 23 unique peptides comprising 288 amino acids were sequenced (see Materials and methods). A degenerate oligonucleotide deduced from peptide 1T13 was used for reverse transcription of $\mathrm{HeLa}$ poly $(\mathrm{A})^{+}$RNA and, together with a degenerate oligonucleotide deduced from a portion of peptide 1T25, was used in a polymerase chain reaction (PCR) amplification of this cDNA. The resulting PCR product was approximately 200 nucleotides and contained an open reading frame capable of encoding the two peptides described plus two additional peptides (2T25 and 2T28). This DNA fragment was labeled and used as a probe to screen a human fetal brain cDNA library. Of the many positive clones obtained, PCR and restriction digests identified four different groups. One member of each was chosen for further analysis. Sequencing analysis showed that the first three clones, $\mathrm{A}$, $\mathrm{B}$, and $\mathrm{C}$, contain the same open reading frame of 707 amino acids, with a predicted molecular mass of $76 \mathrm{kD}$. These three clones differ only in their 3 '-untranslated regions, depending on which of two potential polyadenylation signals are utilized and where adenylation actually begins. Clone $\mathrm{A}$ is the longest and uses the second poly(A) signal, which is 490 nucleotides after the first (Fig. 2A). Clones $\mathrm{C}$ and $\mathrm{B}$ use the first poly(A) signal; but in $C$ the poly(A) tail starts 16 nucleotides after this signal, in B it starts 29 nucleotides after the signal. The fourth clone, F, is identical to the first three until nucle- 


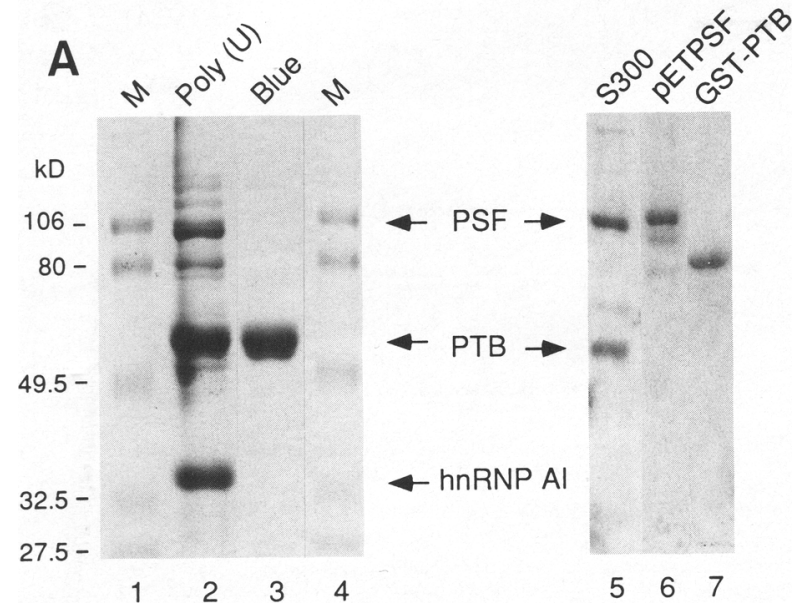

Figure 1. Biochemical complementation. (A). Protein purification. Purification of PTB/PSF from HeLa nuclear extract over DEAE-Sepharose, heparin-agarose and poly $(U)-S e p h a r o s e$ results in copurification of PSF, PTB, and hnRNP Al (lane 2 and denoted at top by the final chromatography resin). Application of these preparations over Cibacron blue agarose or Sephacryl S-300 gel filtration resin yields highly purified PTB (lane 3) or a PTB/PSF large molecular mass complex (lane 5), respectively. Proteins were analyzed on SDS gels and stained with Coomassie blue. Only proteins in the peak gel filtration fraction eluting at $\sim 320 \mathrm{kD}$ are shown in lane 5. Purification of bacterially synthesized PTB and PSF is shown in lanes 6 and 7 , respectively. Size markers are as noted. $(B)$ In vitro splicing in fractionated nuclear extract. HeLa nuclear extracts were fractionated over a single poly(U)-Sepharose column to yield three crude fractions (U500, U1M, and U2AF) that must be recombined to restore spliced product formation (see Materials and methods). A pre-mRNA substrate (pD3 $+\mathrm{DX})$ derived from $\alpha$-tropomyosin was subjected to in vitro splicing in wild-type extract $(\mathrm{NE})$ or reconstituted reactions. The composition of the various recombined reactions is indicated at the top. In the five lanes at the far right, various protein preparations as detailed in $A$ were used in place of the U1M fraction. The precursor, products, and intermediates of splicing are cartooned at right.

otide 2072 (amino acid 662), where the sequence diverges (Fig. 2B). The reading frame of $F$ remains open for 7 additional amino acids, making a total of 669 with a predicted molecular mass of $72 \mathrm{kD}$. Northern blot analysis shows two messages of 2.5 and $3.0 \mathrm{~kb}$ (data not shown) consistent with the sizes of $\mathrm{B}, \mathrm{C}$, and $\mathrm{F}$ for the smaller and $\mathrm{A}$ for the larger. Southern blot analysis (data not shown) shows a single gene encoding these RNAs, suggesting that the two different forms represented by clones $\mathrm{B}$ and $\mathrm{F}$ are derived by alternative splicing (Fig. 2C).

The predicted size of the protein encoded by the larger clones is $76 \mathrm{kD}$, significantly smaller than the experimentally determined size of $100 \mathrm{kD}$. This discrepancy could be the result of missing sequences at the $5^{\prime}$ end of the clone because no stop codons are found in-frame upstream of the designated initiation methionine. However, in vitro translation of clones $\mathrm{B}$ and $\mathrm{F}$ beginning at the designated methionine yields products that comigrate with HeLa-purified PSF (Fig. 3A), and size estimates from Northern blots are in agreement with cDNA lengths. In addition, the protein encoded by the cDNA contains all of the microsequenced peptides described above. Furthermore, many of the clones obtained from library screening stop at the first nucleotide shown in

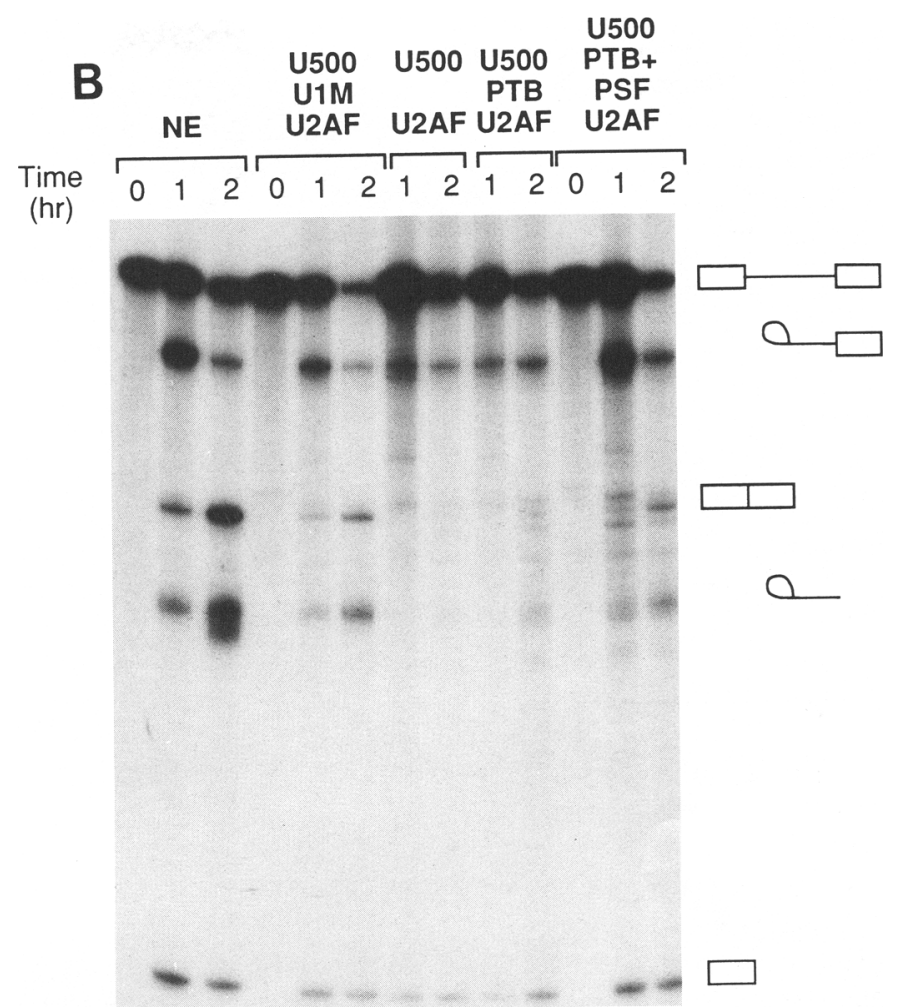

Figure 2A, and multiple 5' RACE (rapid amplification of cDNA ends) clones (Frohman 1990) also stop at this point. We conclude that our assignment of the initiation methionine is correct and that the protein migrates anomalously. Should 5' sequences be missing, they are not functionally important (see below).

Both isoforms of PSF are basic with predicted pIs of 10.3 for B and 10.0 for $F$. Both contain two consensus RNA-binding domains, 80-amino-acid regions containing conserved hydrophobic and aromatic residues (Fig. 2; Bandziulis et al. 1989; Kenan et al. 1991). Both clones also contain a repeated sequence, RGG, in which the arginine is modified, most likely to dimethyl arginine (see Materials and methods; Beyer et al. 1977). This motif has recently been shown to be capable of binding RNA (Kiledjian and Dreyfuss 1992), although the effect of arginine modifications on this binding is not known. Perhaps the most striking sequence motif in PSF is an amino-terminal region very rich in prolines and glutamines. The sequence is $38 \%$ proline over a region of 229 amino acids near the amino terminus. A more limited stretch of 48 amino acids in this region is $88 \%$ proline and glutamine (Fig. 2A,C).

Other than similarities to proline-rich proteins and other RNA-binding proteins, a search of the gene banks 
A

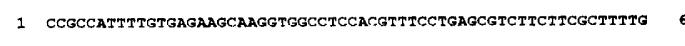

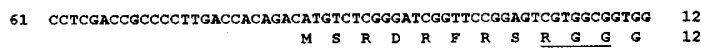
121 CGGTGGTGGCTTCCACAGGCGTGGAGGAGGCGGCGGCCGCGGCGGCCTCCACGACTTCCG 19 13 G G G F H R 181 TTCTCCGCCGCCCGGCATGGGCCTCAATCAGAATCGCGGCCCCATGGGTCCTGGCCCGGG $\begin{array}{lllllllllllllllllllll}33 & S & P & P & P & G & M & G & \text { D } & N & Q & N & R & G & P & M & G & P & G & P & G\end{array}$

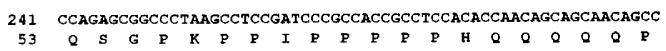
301 ACCACCGCAGCAGCCACCGCCGCAGCAGCCGCCACCGCATCAGCCGCCGCCGCATCCACA

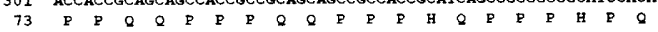

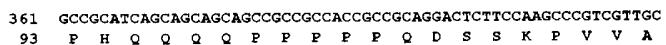
421 TCAGGGACCCGGCCCCGCTCCCGGAGTAGGCAGCGCACCACCAGCCTCCAGCTCGGCCCC

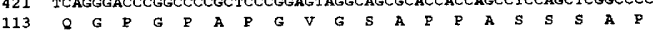
481 GCCCGCCACTCCACCAACCTCGGGGGCCCCGCCAGGGTCCGGGCCAGGCCCGACTCCGAC $\begin{array}{lllllllllllllllllllll}133 & P & A & T & P & P & T & S & G & A & P & P & G & S & G & P & G & P & T & P & T\end{array}$ 541 CCCGCCGCCTGCAGTCACCTCGGCCCCTCCCGGGGCGCCGCCACCCACCCCGCCAAGCAG 153 P P P A $\mathrm{V}$ T S A $P$ P 173 G V P T T P P 661 GGGCCCGGGTCCAGGGCCTAAGCAGGGCCCAGGTCCGGGTGGTCCCAAAGGCGGCAAAAT 721 GCCTGGCGGGCCGAAGCCAGGTGGCGGCCCGGGCCTAAGTACGCCTGGCGGCCACCCCAA

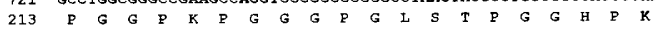
781 GCCGCCGCATCGAGGCGGCGGGGAGCCCCGCGGGGGCCGCCAGCACCACCCGCCCTACCA 233 P 841 CCAGCAGCATCACCAGGGGCCCCCGCCCGGCGGGCCCGGCGGCCGCAGCGAGGAGAAGAT 253 Q $Q$ A $A$ H $Q$ G $P$ P $P$ C $\begin{array}{lllllllllllllllllllll}273 & S & \text { O } & \text { S } & \text { E } & \text { G } & \text { F } & \text { K } & \text { A } & \text { N } & \text { I } & \text { S } & \text { L } & \text { L } & \text { R } & \text { R } & \text { P } & \text { G } & \text { E } & \text { K } & \text { T }\end{array}$

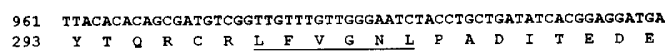

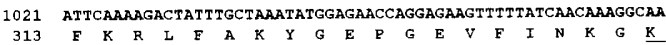
1081 AGGATTCGGATTTATTAAGCTTGAATCTAGAGCTTTGGCTGAAATTGCCAAAGCCGAACT $\begin{array}{lllllllllllllllllllll}333 & G & F & G & E & I & K & L & E & S & R & A & L & A & E & I & A & K & A & E & L\end{array}$ 1141 GGATGATACACCCATGAGAGGTAGACAGCTTCGAGTTCGCTTTGCCACACATGCTGCTGC

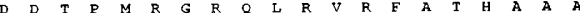
1201 CCTTTCTGTTCGTAATCTTTCACCTTATGTT TCCAATGAACTGTTGGAAGAAGCCTTTAG \begin{tabular}{llllllllllllllllll}
373 & $L$ & $S$ & $V$ & $R$ & $N$ & $L$ & $S$ & $P$ & $Y$ & $V$ & $S$ & $N$ & $E$ & $L$ & $L$ & $E$ & \\
\hline
\end{tabular}

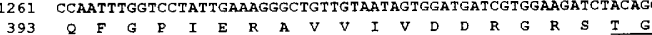
1321 GAAAGGCATTGTTGAATTTGCTTCTAAGCCAGCAGCAAGAAAGGCATTTGAACGATGCAC

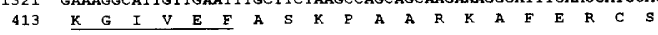

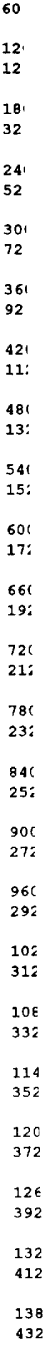

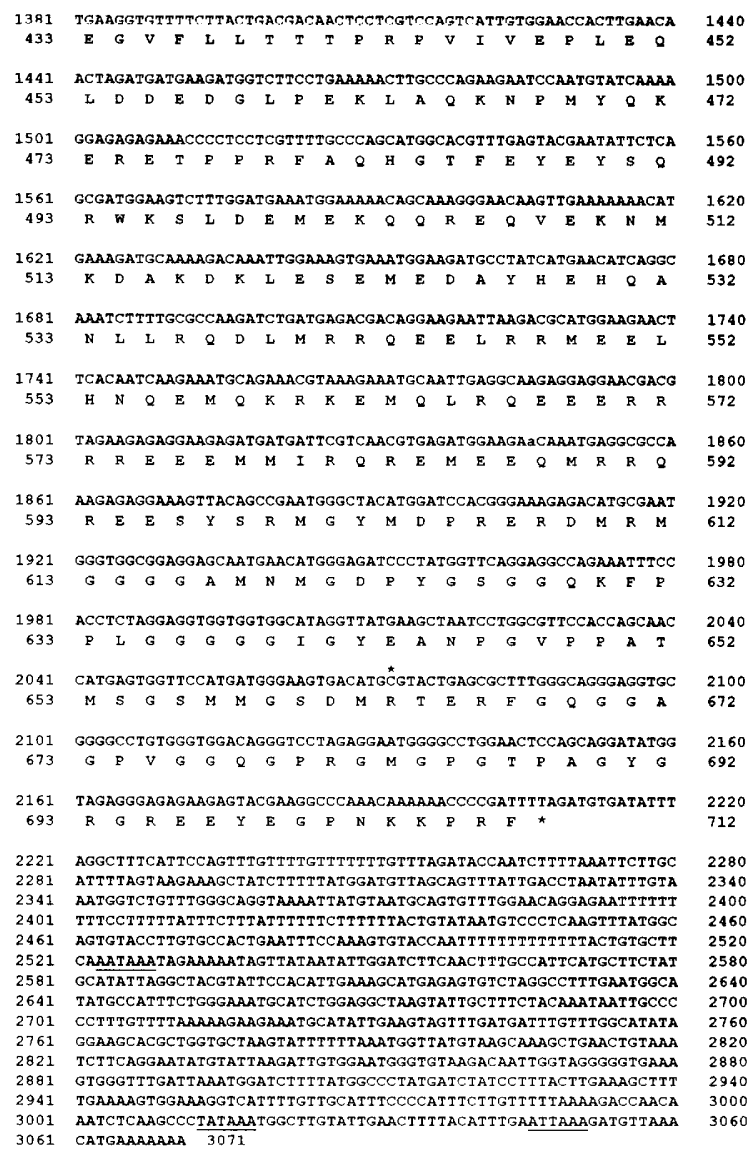

\section{B}

2072 GTAAGAATGATTGATGTTGGCTGATATTGGAGTGCTCATTCACATGAAGTGGATAGATAC 2131 663 V R M I D V G *

2132 TTCTCAAGACATCACACAGCGTGAGTCAATCAAGGAGGGAAGCCACAAGCAGACTGACAA 2191 2192 CGTTTCTAGCAGGATCAGGTGAGCTGTGTCCAGAAAACCAACGAGAAGGAGTGGAAGGAG 2251 2252 GAATGAACGTTTCATTCTCGTTAATAAAGGCATTATCCTAATTTAAAAAAAAAAAAAAAAA 2311 2312 aAaAaAaA 2319

Figure 2. Sequence of alternatively spliced forms of PSF. (A) Nucleotide and deduced amino acid sequence of PSF clone A. Underlined regions denote conserved RNA-binding domains or potential polyadenylation signals. The asterisk $(*)$ above nucleotide 2072 indicates the divergence point of PSF clone F. $(B)$ Nucleotide sequence of the $3^{\prime}$ end of PSF clone F. The nucleotide sequence is shown beginning at the point at which clone $F$ diverges from clone A. $(C)$ Alternative splicing pattern of PSF. Four classes of cDNA clones were obtained from library screening and sequencing of multiple PSF clones. Clones A, B, and C have the identical open reading frame but differ in

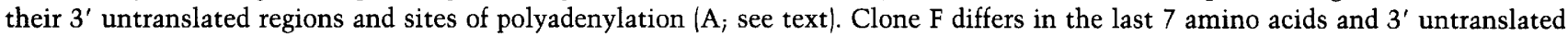
region. Both isoforms contain two conserved 80-amino-acid RNA-binding domains (RBD-1 and RBD-2), as well as an amino terminus rich in prolines $(\mathrm{P})$ with a subregion rich in prolines and glutamines $(\mathrm{P}, \mathrm{Q}$; shaded boxes).

for related sequences revealed no significant homologies with other proteins except the surprising finding that the carboxyl terminus of PSF had already been sequenced and reported. Gower et al. (1989) utilized a monoclonal antibody specific to a human myoblast cell-surface antigen (24.1D5) and isolated a partial cDNA clone of PSF beginning at the EcoRI site at nucleotide 1019. Because
PSF contains RNA-binding consensus sequences, is found in the nucleus, and does not contain any transmembrane regions, the most logical explanation for this apparent discrepancy is that mAb 24.1D5, in addition to its reactivity with a human myoblast membrane protein, cross-reacts with PSF. In support of this, Western blots using the 24.1D5 antibody show that it recognizes PSF 

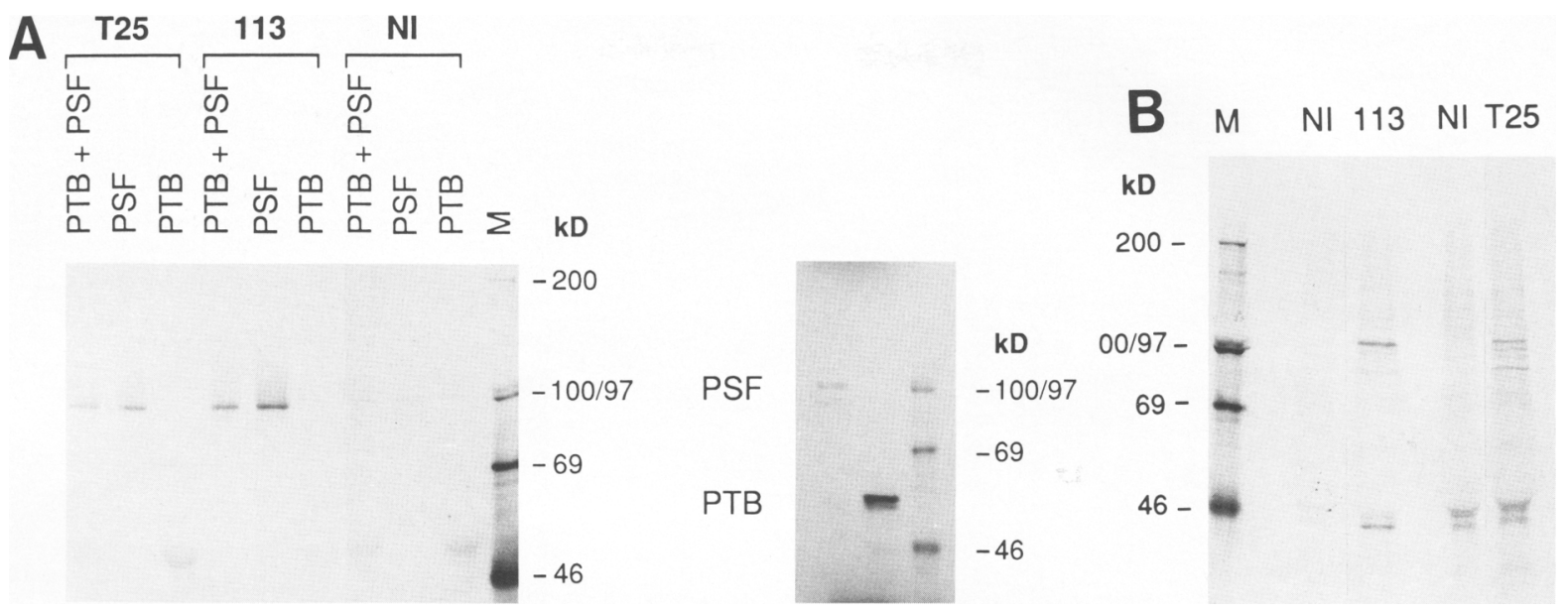

Figure 3. Antibody characterization. $(A)$ Immunoprecipitation of in vitro-translated PTB and PSF by anti-PSF antibodies. In vitrotranslated PSF clone B and PTB are shown at right. These proteins were immunoprecipitated from reticulocyte lysates by nonimmune antibody (NI), polyclonal antibody 113, or anti-peptide antibody T25. Equal volumes of PSF, PTB, or a mixture of the two were immunoprecipitated and subjected to electrophoresis. Marker sizes are as indicated. $(B)$ Immunoprecipitation of PSF from ${ }^{35} S$-labeled HeLa cell extracts. Whole-cell extracts from ${ }^{35} \mathrm{~S}$-labeled HeLa cells were prepared, and immunoprecipitations were performed with nonimmune (NI), affinity-purified 113, or affinity-purified T25 antibodies and analyzed as in $A$.

(J.G. Patton, unpubl.; see Gower et al. 1989). In addition, immunofluorescent staining of fixed cells with this antibody shows a speckled nuclear pattern that colocalizes with other splicing factors, including SC35, U2B", and U1 snRNP (data not shown). In Gower et al. (1989), the antibody stained myoblast membranes, probably because the cells were not fixed to maintain the viability of the membranes.

\section{PSF is an essential pre-mRNA splicing factor}

To determine whether PSF plays a role in splicing, we prepared antibodies against two different peptides (1T13 and 1T25) and against bacterially synthesized PSF clone B (antibody 113). Characterization of these antibodies was carried out by immunoprecipitation of in vitrotranslated ${ }^{35} \mathrm{~S}$-labeled PSF and PTB and ${ }^{35}$ S-labeled HeLa extracts. Figure 3, A and B, shows that the T25 and 113 antibodies specifically immunoprecipitate PSF from either reticulocyte lysates or HeLa cell extracts. This was confirmed by Western blot analysis with the same antibodies (data not shown).

We used these antibodies to inhibit in vitro splicing assays by the direct addition of increasing amounts of anti-PSF IgG. As shown in Figure 4A, T25 antibodies inhibited in vitro splicing of $\alpha$-tropomyosin-derived splicing substrates in a dose-dependent manner while neither nonimmune nor anti-PTB antibodies inhibited splicing at the highest doses tested. The second antipeptide antibody (T13) did not inhibit at $100 \mu \mathrm{g}$ of $\operatorname{IgG}$ but did inhibit at $200 \mu \mathrm{g}$. Significantly, poly|U)-purified PTB/PSF (Fig. 1A, lane 2) was able to out-compete the antibody and relieve inhibition, attesting to the specificity of the inhibition. Prior heat treatment of the antibody also destroyed its ability to inhibit splicing. Figure 4B shows a similar set of inhibition experiments using increasing doses of 113 antibody. Again, splicing is inhibited. However, in this set of experiments, additional specific protein competitors were used to relieve the inhibition. At $50 \mu \mathrm{g}$ of antibody, bacterially synthesized PSF (pETPSF; Fig. 1A, lane 6), poly(U)-purified PTB/PSF (Fig. 1A, lane 2), and purified PTB (Fig. 1A, lane 3) were all able to restore both steps of splicing. However, at $100 \mu \mathrm{g}$ of antibody, only pETPSF and, to a lesser extent, the poly(U)-purified PTB/PSF were able to restore such splicing activity. Purified PTB was unable to restore spliced product formation at $100 \mu \mathrm{g}$ of antibody 113. Similar inhibition experiments were carried out with $\mathrm{mAb}$ 24.1D5 and showed the same results. Although the inhibition experiments just described argue strongly that PSF is an essential pre-mRNA splicing factor, the inhibition that we detect could formally be the result of the sequestration of unidentified cross-reacting proteins. However, the fact that several independently generated antibodies against PSF inhibited splicing suggests strongly that PSF is an essential splicing factor.

To further verify that PSF plays an essential role in pre-mRNA splicing, we sought to determine whether splicing could proceed in the absence of PSF. Consequently, we passed nuclear extracts over an anti-PSF affinity resin to specifically deplete PSF. Although complete depletion was not observed, significantly less PSF was detected in the depleted extracts (Fig. 4C). When splicing reactions are carried out in this extract, they are inhibited for spliced product formation compared with mock-depleted extracts, which are mostly unaffected (Fig. 4D). Importantly, the block to product formation can be complemented with bacterially produced PSF but not with the pET protein control, effectively ruling out the possibility that unrelated cross-reacting proteins are 
A

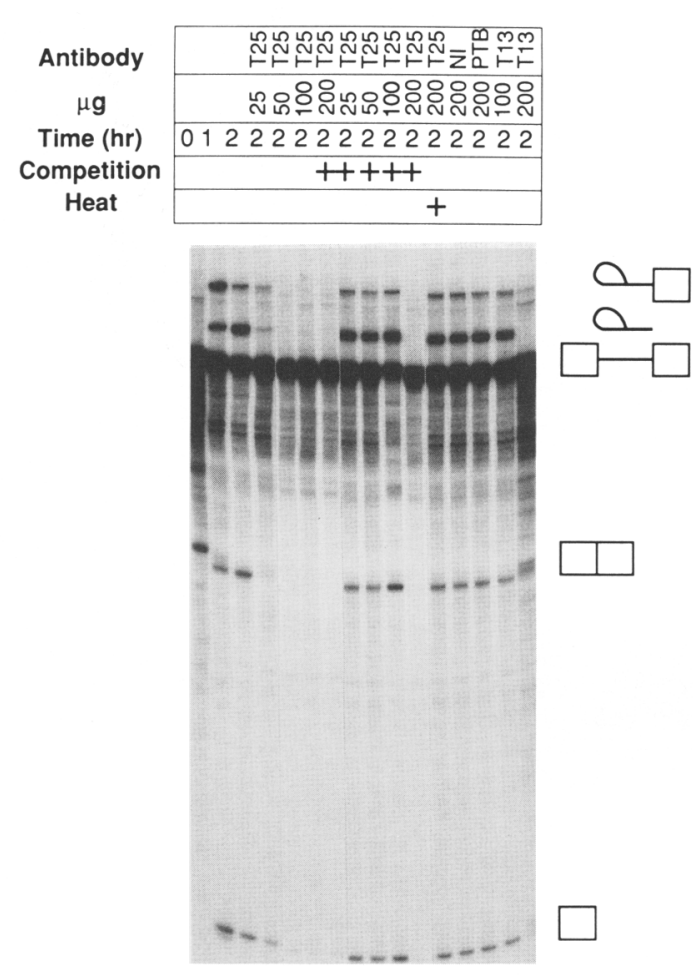

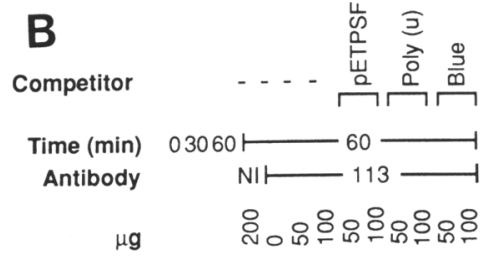

$\mu \mathrm{g}$

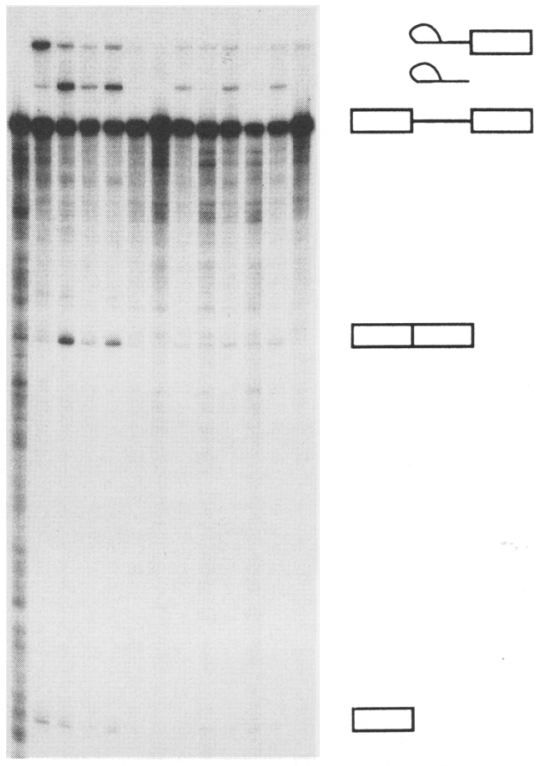

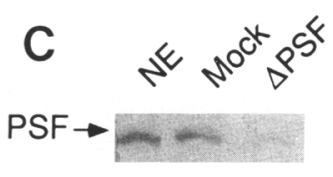

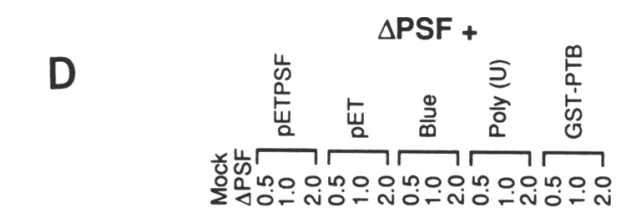

Time (min) 03060

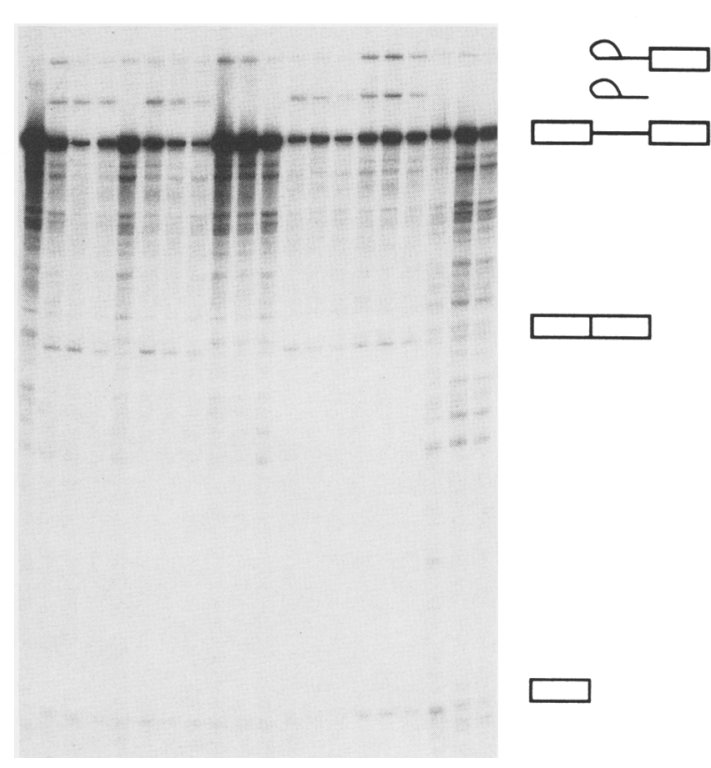

Figure 4. PSF is an essential pre-mRNA splicing factor. $(A)$ Inhibition of pre-mRNA splicing by $\mathrm{T} 25$ antibodies. In vitro splicing of pG3 + DS pre-mRNA was carried out in HeLa nuclear extract and with increasing amounts of IgG from the indicated antibody. T25 antibodies (T25), nonimmune antibodies (NI), PTB antibodies, or T13 anti- peptide antibodies are as indicated. Competition refers to the addition of purified proteins (Fig. 1A, lane 2) during the preincubation between IgG and protein A-Sepharose beads before splicing (see Materials and methods). Heat refers to denaturation of the IgG at $65^{\circ} \mathrm{C}$ before the addition to the splicing reaction. Precursor, products, and intermediates of the splicing reaction are cartooned at right. $(B)$ Inhibition of pre-mRNA splicing by 113 antibodies. In vitro splicing of $\mathrm{pG} 3$ + DS pre-mRNA was performed in the absence or presence of the indicated amount of antibody 113 or nonimmune IgG. The competitor proteins during the preincubation were either bacterially synthesized PSF (pETPSF; Fig. 1A, lane 6), poly(U)-purified PTB/PSF (Fig. 1A, lane 2) or purified PTB (Fig. 1A, lane 3). (C) Depletion of PSF from nuclear extract. HeLa nuclear extracts were immunodepleted of PSF by immunoaffinity chromatography. A Western blot of wild-type nuclear extract (NE), mock-depleted extract, or PSF-depleted extract is shown using T25 antibody. (D) Depletion of PSF inhibits premRNA splicing. Splicing of pG3 + DS pre-mRNA in wild-type, mock-depleted, or PSF-depleted nuclear extracts is shown at the indicated time. Complementing proteins are as in $B$ and correspond to those shown in Fig. 1A. 
responsible for the effect that we have detected. Poly(U)purified PTB/PSF and purified PTB also rescue spliced product formation, but bacterially synthesized PTB does not. Thus, anti-PSF antibodies directly inhibit splicing and depletion of PSF also inhibits splicing, arguing further that PSF is an essential pre-mRNA splicing factor.

Similar experiments utilizing PTB antibodies and immunodepletion of PTB did not result in any inhibition of splicing. Nevertheless, purified PTB fractions are able to partially rescue anti-PSF antibody-inhibited reactions (Fig. 4B) and biochemically depleted extracts (Fig. 1B) and can complement extracts that are specifically immunodepleted of PSF (Fig. 4D): These results can be explained by the fact that the purified PTB preparation contains limiting amounts of PSF (data not shown). The fact that bacterially produced PTB does not restore activity supports the idea that the rescue seen with purified PTB is the result of contaminating PSF. However, it is possible that the bacterially produced glutathionine $S$-transferase (GST)-PTB fusion protein is not functional. Nevertheless, the rescue obtained with bacterially synthesized PSF argues strongly that the restoration of activity is solely the result of PSF. Also, comparison of the rescue activity between purified PTB and poly/U)-purified PTB/ PSF shows a correlation between the amount of PSF in these fractions and the amount of rescue activity seen in Figure 4D. In the presence of increased levels of PSF, both steps of splicing are activated. Complementation with purified PTB (Figs. 1B and 4D) primarily allows progression of only the second step of splicing, consistent with the presence of limiting amounts of PSF in the purified PTB preparation.

\section{PSF is required early in spliceosome formation}

In the complementation experiments shown in Figures $1 B$ and 4D, depleted extracts retained limiting amounts of PSF that likely allow the first step of splicing to proceed to variable extents. However, both steps of splicing can be completely inhibited in the presence of saturating amounts of PSF antibodies (Fig. 4A,B). To determine where PSF is required in the splicing pathway, we subjected splicing reactions performed in PSF-depleted extracts to native gel electrophoresis (Konarska and Sharp 1986). Analysis of splicing complexes in this manner allows the detection of at least three complexes, referred to as $\mathrm{H}, \mathrm{A}$, and $\mathrm{B}$. $\mathrm{H}$ complex is the first association of proteins with the pre-mRNA in the absence of ATP and is dominated by the association of hnRNP proteins, including PTB (which is the same as hnRNP I; Bennett et al. 1992b). In the presence of ATP, U2 snRNP, along with other proteins, forms a stable association with the premRNA referred to as the A complex. Ul is necessary to form this complex but does not remain stably bound under these electrophoretic conditions (Zillman et al. 1987, 1988|. Complex B represents the complete spliceosome. As shown in Figure 5, extracts specifically depleted of PSF are severely inhibited for the formation of A complex. Only small amounts of A and B complex are detected, consistent with the minor amounts of PSF re-

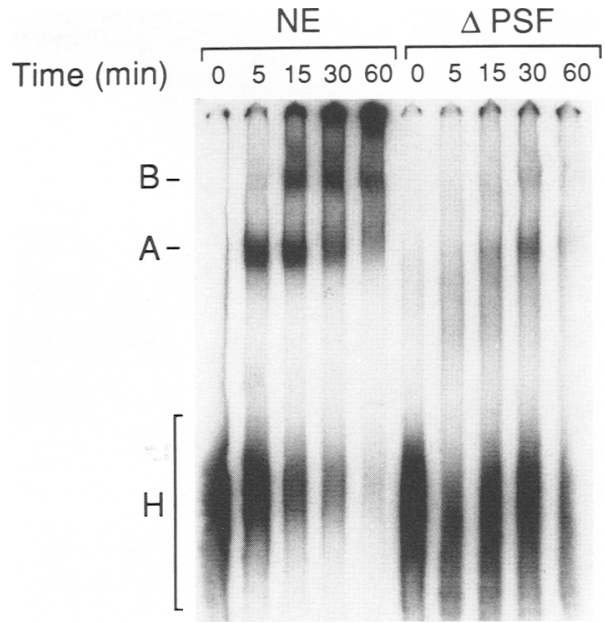

Figure 5. PSF acts early in spliceosome formation. Splicing reactions were performed in the same PSF-depleted extract as in Figure 4, C and D. Following splicing for the indicated time, reactions were subjected to native gel electrophoresis. $H, A$, and $\mathrm{B}$ complexes are as in the text.

maining in these depleted extracts. However, the kinetics of formation of these complexes is retarded, and the quantitative amounts are drastically lower than those seen in nuclear extracts or mock-depleted extracts. Given that direct addition of anti-PSF antibodies to the splicing reaction inhibits both steps of splicing and that only small amounts of A complex can form when PSF is limiting, the data are most consistent with PSF playing a role in the early steps of spliceosome formation.

\section{PSF binds specifically to polypyrimidine tracts}

Because PSF contains two consensus RNA-binding domains, we then sought to confirm that PSF actually binds RNA and to determine the sequence specificity of binding. PTB was first identified by UV cross-linking to pyrimidine-rich RNAs, and it shows a marked preference for poly(U) RNA (Garcia-Blanco et al. 1989; Gil et al. 1991; Patton et al. 1991). When bacterially synthesized PSF was subjected to similar analysis, we found that it also binds polypyrimidine-rich RNAs in a manner apparently identical to PTB (Fig. 6). PSF shows specific binding to B3P3 RNA, the branchpoint/polypyrimidine tract element upstream of exon 3 in $\alpha$-tropomyosin (Mullen et al. 1991; Patton et al. 1991). This element is the major determinant in the default selection of exon 3 over exon 2 between these mutually exclusive exons, and PTB binds to it with high affinity. In addition, PSF binds preferentially to poly|U) RNA with little detectable binding to $\operatorname{poly}(A)$, poly $(\mathrm{G})$, or poly $(\mathrm{C})$ homoribopolymers and no detectable binding to yeast tRNA. Therefore, both PSF and PTB display a marked preference for binding to the branchpoint/polypyrimidine tract of mammalian introns. 


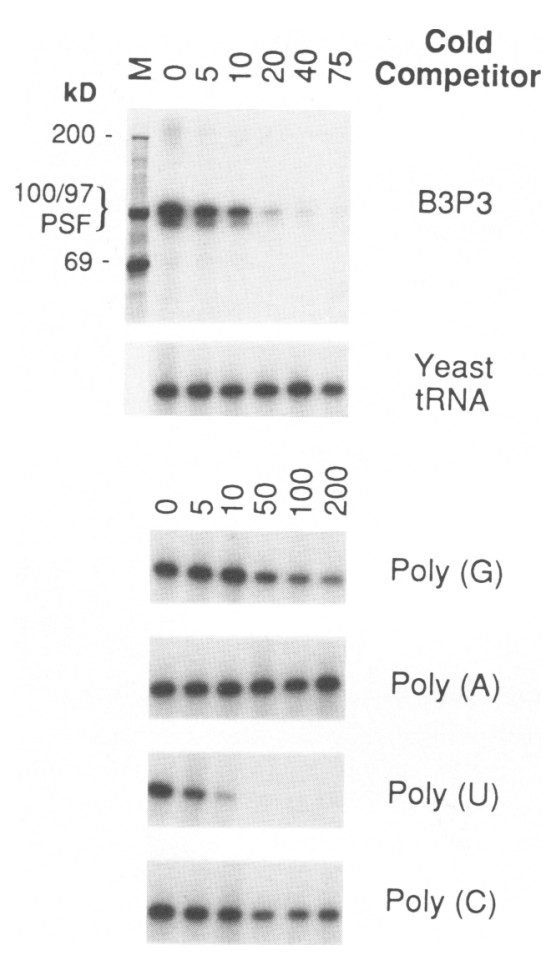

Figure 6. PSF binds pyrimidine-rich RNAs. UV cross-linking of bacterially synthesized PSF (Fig. 1A, lane 6) to ${ }^{32}$ P-labeled B3P3 RNA was performed in the absence or presence of cold competitor RNAs. Labeled proteins were analyzed on SDSacrylamide gels. The molar excess of cold self-competitor RNA (cold B3P3) or yeast tRNA is as shown at the top. For competition by increasing amounts of homoribopolymer RNAs, the amount of mass excess of competitor is as shown. Marker proteins and PSF are denoted at left.

\section{Association of PSF and PTB}

Inhibition of splicing by anti-PSF antibodies and immunodepletion of PSF both suggest that PSF plays an essential role in pre-mRNA splicing. However, PTB does not appear to be essential by antibody inhibition, biochemical complementation, or pre-spliceosome formation (Jamison et al. 1992). Nevertheless, these proteins copurify and seem to form a large complex. Consistent with this, anti-PTB antibodies immunoprecipitate both PTB and PSF from HeLa cells (Patton et al. 1991). However, anti-PSF antibodies only immunoprecipitate PSF (Fig. 3). A possible explanation for this discrepancy is that the epitopes recognized by the PSF antibodies are not accessible when PSF is complexed to PTB or that the antibodies disrupt the complex. Also, we have no knowledge about the relative amounts of each protein in the free versus complexed state. Thus, the lack of coimmunoprecipitation does not preclude PSF and PTB association.

To further investigate the ability of these two proteins to associate, we used two different in vitro-binding assays. We probed Western blots of either HeLa nuclear extract or purified PTB/PSF (Fig. 1A, lane 2) with in vitro-translated ${ }^{35} \mathrm{~S}$-labeled PSF (Fig. 7A) Under these stringent conditions, PSF specifically binds to PTB. In addition, a ${ }^{32} \mathrm{P}$-labeled bacterially produced PTB probe binds to PSF on Western blots (data not shown). To further verify the interaction between these two proteins, we incubated ${ }^{35}$ S-labeled PTB or PSF with resin-bound proteins. In vitro-translated PSF was able to specifically associate with PTB and did not show significant association with a series of resin-bound control RNA-binding proteins (Fig. 7B). Similarly, ${ }^{35}$ S-labeled PTB specifically interacts with resin-bound PSF and does not bind any of the resin-bound control proteins, although it is capable of self interaction (Fig. 7C). Thus, PTB and PSF specifically interact in vitro. More work will be necessary to completely map the specific amino acids of both PTB and PSF that are necessary for their interaction. Nevertheless, the results clearly support previous data suggesting a specific interaction between these two proteins in vivo and in vitro.

\section{Discussion}

We have described the isolation of cDNA clones encoding the protein that associates with PTB and have termed this protein PSF. Dissection of the individual roles played by each protein in the splicing process suggests that PSF is an essential splicing factor and PTB is not. Antibodies against PSF can inhibit pre-mRNA splicing, and this inhibition can be relieved by out-competing the antibody with partially purified PSF preparations and
Figure 7. Specific interaction between PSF and PTB. (A) PSF binds filter-bound PTB. A Western blot of total nuclear extract or purified PTB/PSF (Fig. 1A, lane 2) was probed with ${ }^{35}$ S-labeled PSF. PTB and markers are as indicated. $(B)$ Р $Г \mathrm{~B}$ binds resin-bound PSF. In vitro-translated PTB was incubated with the indicated RNAbinding protein bound to either glutathione agarose or Ni-NTA resin. Beads were washed, and bound proteins were eluted by boiling before electrophoresis. (C) PSF binds resin-bound PTB. In vitro-translated PSF clone $F$ was incubated with the indicated RNA-binding proteins as in B. Similar results were obtained with PSF clone $B$.

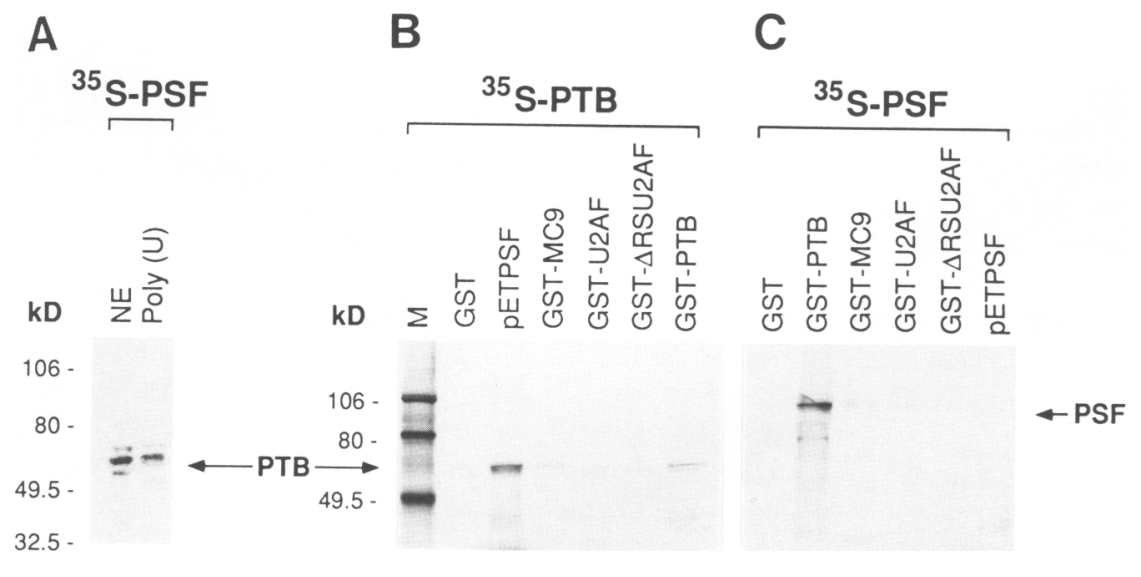


bacterially synthesized PSF. In addition, when nuclear extracts are immunoaffinity depleted of PSF, splicing is inhibited. This inhibition can again be relieved by complementation with purified PSF. Colocalization of PSF with snRNPs and other splicing factors, including SC35, U2B", and U1snRNP, also supports the role of PSF in pre-mRNA splicing. Furthermore, PSF is identical to previously identified mammalian spliceosome-specific proteins, SAP 102 and SAP 68 (a breakdown product of PSF; Bennett et al. 1992a; R. Reed and M. Bennett, pers. comm.). Thus, PSF is a spliceosome protein that is necessary for pre-mRNA splicing. Corresponding experiments with PTB antibodies have not supported a similar role for PTB, and further analysis has suggested that PTB is not required for pre-spliceosome complex formation (Jamison et al. 1992; J.G. Patton, unpubl.). Although these experiments are complicated by the fact that PTB is much more abundant than PSF and thus more difficult to deplete, the overall conclusion is most consistent with a nonessential role for PTB. Nevertheless, PTB could still play an important role in splicing like that of hnRNP A1, which can affect 5' splice site selection even though it is not required for splicing (Ben-David et al. 1992; Mayeda and Krainer 1992). PTB may play a similar role in 3' splice site selection. It should be noted that we have not demonstrated whether PSF requires association with PTB for function. In all of the depletion/complementation experiments that show an individual requirement for PSF, PTB is present in the depleted extracts and is available for binding to PSF upon complementation. Further experiments will be needed to determine whether PSF requires in vivo association with PTB for splicing activity.

\section{Primary structure of PSF}

The cDNA clones that we have sequenced predict an open reading frame of 707 or 669 amino acids for the two isoforms of PSF. Because Southern blots suggest that PSF is encoded by a single gene, the two forms are most likely produced by alternative splicing. The primary sequence of PSF reveals the presence of two consenus RNA-binding domains. In addition, it contains three RGG repeats that have recently been proposed to have RNA-binding ability (Kiledjian and Dreyfuss 1992). Presumably, the arginines in the RGG repeats play a crucial role in RNA-binding, given that a single arginine residue is capable of mediating RNA recognition /Calnan et al. 1991). However, in PSF these arginines are modified, most likely to dimethyl arginine. This would abolish the proposed $\mathrm{H}$-bonding interactions between the arginine side chains and the RNA. Should the RGG motifs play a role in RNA-binding, understanding the regulation and developmental timing of the arginine methylase responsible for such modification will be necessary. Regardless of which domains are responsible, PSF binds to RNA and displays a sequence preference for polypyrimidines identical to that of PTB. Both proteins bind the functionally important polypyrimidine tract of mammalian introns.

The amino terminus of PSF is characterized by a strik- ing content of prolines and glutamines. This region, encompassing amino acids $34-263$ is $38 \%$ proline, with a more limited domain (amino acids 56-104) consisting of $88 \%$ proline and glutamine. Several RNA-binding proteins contain similar proline or proline/glutamine motifs (P/Q; Adam et al. 1986; Sachs et al. 1986; Sillekens et al. 1987, 1988; Piñol-Roma et al. 1989; Rokeach et al. 1989). For the U1 snRNP-specific protein C, these sequences have been proposed to augment U1-5' splice site interactions (Heinrichs et al. 1990). It is therefore tempting to propose that this region functions in premRNA splicing as a protein-protein interaction domain necessary for assembling the multiple components of the spliceosome. Comparison of other proteins that function in similar macromolecular assemblies supports this hypothesis. Several transcription factors have been found to contain regions rich in proline or proline/glutamine (Courey and Tiian 1988; Muller et al. 1988; Santoro et al. 1988; Williams et al. 1988). The P/Q regions of CTF$1 / \mathrm{NF}-1$ and $\mathrm{Sp}-1$ are the transcription activation domains (Courey and Tjian 1988; Tanese et al. 1991). Thus, the proline or proline/glutamine domains may act as a binding site for recognition and assembly of additional factors during the formation of transcription complexes and spliceosomes. In this manner, the functional role of the P/Q domain of PSF may be similar to the role proposed for the R/S domains found in U2AF and suppressor of white apricot ( $\mathrm{Li}$ and Bingham 1991; Zamore et al. 1992) This domain is required for function in U2AF, and the $\mathrm{R} / \mathrm{S}$ domain may function as a subnuclear localization signal in suppressor of white apricot. Both functions are likely mediated by protein-protein interactions.

\section{Is PSF identical to intron-binding protein?}

In addition to PSF and U2AF, a third splicing factor that binds to the 3 ' splice site is intron-binding protein (IBP). IBP is an Sm-containing antigen that may be part of U5 snRNP (Gerke and Steitz 1986, Tazi et al. 1986). Initial reports described IBP to be either 100 or $70 \mathrm{kD}$, with the suggestion that the $70-\mathrm{kD}$ protein may be a breakdown product of the $100-\mathrm{kD}$ protein. This characteristic breakdown product is highly similar to that reported here for PSF (SAP 68). In addition, we find that the chromatographic properties of PSF change with increasing $\mathrm{Mg}^{2+}$ concentrations as do those of IBP. However, IBP is an Sm antigen, and we have not been able to detect any reactivity of PSF with any of several Sm antibodies. Furthermore, Western blots of purified U5 snRNPs do not show reactivity with any of our anti-PSF antibodies, and none of these antibodies can specifically immunoprecipitate U5 snRNP (data not shown). Thus, it does not appear that PSF is identical to IBP, but final confirmation will require the cloning and sequencing of this protein.

\section{PSF is required early in spliceosome assembly}

Depletion of PSF from splicing extracts suggests that PSF acts before A complex formation (Fig. 5). However, SAP 102 (PSF) is found only in full spliceosomes and not in 
pre-spliceosomes (Bennett et al. 1992a). The absence of PSF from affinity-purified pre-spliceosomes may reflect a lack of stability of PSF with these earlier complexes rather than an absence from such complexes. Such an absence is noted with the R/S family of proteins, which are known to be required for the early steps of spliceosome formation (Krainer et al. 1990a; Bennett et al. 1992a). The conditions used to isolate pre-spliceosomes may disrupt the association of both PSF and the R/S proteins from these complexes. Saturating levels of antiPSF sufficient to sequester all available PSF inhibit splicing, suggesting that PSF acts before the first step of splicing (Fig. 4A,B). In addition, native gel analysis strongly suggests that depletion of PSF retards assembly of A complexes (Fig. 5), supporting an early role for PSF in spliceosome assembly.

\section{PSF forms a large complex with PTB}

We originally identified PSF based on its copurification and association with PTB. Individually, PTB does not appear to be a necessary pre-mRNA splicing factor. What, then, is the role of the PTB/PSF complex and of PTB? One possibility is that PTB and PSF are not associated in vivo and that the association we and others detect is an in vitro artifact. However, PTB antibodies immunoprecipitate both PTB and PSF from HeLa cell extracts, supporting the existence of a complex in vivo (Patton et al. 1991). In contrast, PSF antibodies do not immunoprecipitate both proteins. To further investigate this complex, we probed Western blots with labeled PSF and detected its association with PTB. A second set of in vitro-binding assays detected specific interactions between in vitro-translated PTB or PSF and its resin-bound counterpart. These results confirm gel filtration data suggesting that PTB and PSF are capable of forming a large complex. Of the two, only PSF appears to be an essential splicing factor.

What, then, is the role of PTB? PTB binds efficiently to the polypyrimidine tract, and its binding correlates exactly with $3^{\prime}$ splice site selection in a variety of constructs (Mullen et al. 1991). One possible role for PTB could be in mediating the binding of several splicing factors to the branchpoint/polypyrimidine tract. This cisacting element is essential for efficient formation of spliceosomes (Frendeway and Keller 1985; Reed and Maniatis 1985; Ruskin and Green 1985; Bindereif and Green 1986, Smith et al. 1989b|. The abundance levels of PTB may allow it to bind to the polypyrimidine tracts of nascent transcripts identifying these sequences for later binding of splicing factors that can displace PTB during spliceosome formation in the presence of ATP. This is supported by the fact that PTB is more abundant in prespliceosomes than in spliceosomes (Bennett et al. 1992a), and the binding of PTB to RNA decreases under conditions allowing spliceosome formation (S.A.Mayer, J.G. Patton and B. Nadal-Ginard, in prep.). PTB may then influence splice site selection by initially determining the strength of a polypyrimidine tract and reserving binding sites for essential splicing factors such as PSF, which is potentially carried into the spliceosome by PTB, and other polypyrimidine tract-binding proteins such as U2AF. In $\alpha$-tropomyosin, the selection of alternative exons 2 and 3 is based on competition between the corresponding branchpoint/polypyrimidine tracts of each exon (Mullen et al. 1991). Taking this as a model system, it is conceivable that PTB is the primary competitive determinant that initally measures the strength of the competing elements and stimulates kinetically favored spliceosome assembly on the stronger intron, thus determining splice site selection in alternatively spliced pre-mRNAs. Such a role for PTB and other hnRNP proteins has been proposed and is supported by the fact that these proteins bind differentially to RNA transcripts (Bennett et al. 1992b).

\section{Materials and methods \\ Constructs}

Constructs pG3 + DX, pG3 + DS, B3P3, and 121GEX3H (GST-PTB) are as described (Smith and Nadal-Ginard 1989; Smith et al. 1989b; Patton et al. 1991). PTB-GEM consists of the coding sequence of PTB (Patton et al. 1991) plus 21 nucleotides of the 5'-untranslated region cloned downstream of the SP6 promoter in pGem 4 blue. GST-U2AF and GST- - RS U2AF were prepard by insertion of either full-length $U 2 A F$ or a deletion of the $R / S$ region of U2AF into the Gex 2 vector. U2AF cDNA clones were from Zamore et al. (1992). MC9 is a potential human homolog of the yeast splicing protein PRP 9 and was cloned into the Gex 1 vector (M. Chiara, unpubl.).

Extracts, transcriptions, UV cross-linking, and splicing reactions

All standard splicing reactions, HeLa extracts, RNA transcriptions, and UV cross-linking assays were as described (Patton et al. 1991). Separation of splicing extracts over poly(U)-Sepharose columns was as described (Patton et al. 1991). Fractionation in this manner is extremely variable depending on the age of the Sepharose, time of swelling, buffer composition, and running speed. The most consistent results were obtained with extracts that were not completely depleted of PTB or PSF from the U500 fractions. These fractions always allowed the first step of the splicing reaction to proceed with varying efficiency (Fig. 1B). Splicing reactions performed in the presence of fractionated nuclear extracts contained $40 \%$ flowthrough material (U500) and $10 \%$ U1M and U2AF fractions.

Antibody inhibition experiments were performed by incubation of the desired amount of affinity-purified antibody with protein-A-Sepharose beads for $1 \mathrm{hr}$ at $4^{\circ} \mathrm{C}$. The beads were then washed with nuclear extract dialysis buffer $(20 \mathrm{mM}$ Tris at $\mathrm{pH}$ $8.0,100 \mathrm{~mm} \mathrm{KCl}, 0.2 \mathrm{~mm}$ EDTA, $0.5 \mathrm{~mm}$ DTT, and $20 \%$ glycerol), followed by direct assembly of the splicing reaction in the same tube. Reaction volume was $25 \mu \mathrm{l}$, including $3.5 \mu \mathrm{l}$ of protein-A beads. Various purified proteins were added as competitive inhibitors during the IgG-protein-A preincubation.

Detection of splicing complexes on native gel electrophoresis was in $4 \%$ Tris-glycine gels (Konarska and Sharp 1986). Reactions were as described above except that following incubation at $30^{\circ} \mathrm{C}$ for the indicated time, samples were frozen on dry ice, thawed, and supplemented with heparin to $1 / 25 \mathrm{mg} / \mathrm{ml}$ before electrophoresis. 


\section{Protein purification}

PTB was purified as in Patton et al. (1991), consisting of chromatography of HeLa nuclear extracts over DEAE-Sepharose CL6B, heparin-agarose, and poly(U)-Sepharose columns. Further purification of PTB was performed by subjecting the material resulting from these three columns to a fourth resin, cibacron blue agarose. PTB elutes from this resin at $1.0 \mathrm{M} \mathrm{KCl}$ in buffer $\mathrm{A}$ (20 mM Tris at pH 8, $3 \mathrm{~mm} \mathrm{MgCl}_{2}, 0.1 \mathrm{~mm}$ EDTA, $1 \mathrm{~mm}$ DTT, $10 \%$ glycerol, $0.05 \%$ NP-40]. Additional PTB complexed with PSF elutes from this resin at $2.5 \mathrm{M} \mathrm{KCl}$ under these conditions. The PTB/PSF complex was purified by subjecting proteins purified through the poly(U) column step to Sephacryl S-300HR gel filtration chromatography (Patton et al. 1991).

Expression and purification of bacterial GST-PTB was as described (Patton et al. 1991), with modifications following Lin and Green (1991). Bacterial PSF was produced by placing clone $\mathrm{B}$ in $\mathrm{pET}$ 15b (Novagen, Madison, WI) and producing a fusion protein consisting of the amino acids derived from the $\mathrm{pET}$ vector, 4 amino acids encoded by $5^{\prime}$-untranslated sequences, and the PSF open reading frame. Cultures of this construct were diluted $1: 25$ after overnight growth in Terrific Broth (Sambrook et al. 1989), allowed to grow at $30^{\circ} \mathrm{C}$ until the absorbance at $600 \mathrm{~nm}$ was 0.6 , and induced with IPTG at a final concentration of $1 \mathrm{~mm}$. Growth was continued for $4-6 \mathrm{hr}$ at $30^{\circ} \mathrm{C}$ before harvesting and purification under denaturing conditions using a Ni-NTA resin from Qiagen and following the manufacturer's instructions. Purified protein was sequentially dialyzed against decreasing concentrations of urea until final dialysis against nuclear extract dialysis buffer.

\section{Peptide sequencing}

Purified proteins were transferred to nitrocellulose, and the band containing PSF was excised, digested with trypsin, separated, and sequenced as in Patton et al. (1991). The following peptides were sequenced where amino acids are represented in single-letter code; $X$ is unidentified, and $Z$ corresponds to a similarly modified amino acid of abnormal HPLC mobility (most likely arginine): 1T13, FATHAAALSVR; 17TA , FGQGGAGPVYFQGPR; 1T25， LFVGNLPADITEDEFK; 20T20.1, ZGGGGGZGGLHDFR; 2T21, RREEEMMIR; 2T24.1A, GIVEFASKPAAR; 2T24.1B, FAQHGTFEYEYSQR; 2T25, YGEPGEVFINK; 2T28, GFGFIK; 2T29.1, DKLESEMEDAYHEHQANLLR; 2T39, NLSPYVSNELLEEAFSQFGPI; 2T2A, NPMYQK; 2T2B, RQEELR; 2T4A, EEYEGPNKKPR; 2T4B, EMEEQMR; 2T4C, LAQK; 2T5.5A, GREEYEGXNKXPR; 2T5.5B， SZGGGGGGFHR; 2T11.1, QHHPPYHQQHHQGPPPGGPGGR; 2T11.5, SLDEMEK; 2T11.6, LFAK; 2T26A, ANLSLLR; 2T26C, GPMGPGPGQSGPKPPIPPPPPHQQQQQPPPQQPPPQQPPPHQ.

\section{Cloning and sequencing of PSF}

A degenerate oligonucleotide deduced from peptide $1 \mathrm{Tl} 3$ (T13rev) was used to prime reverse transcription of $\mathrm{HeLa}$ poly $(\mathrm{A})^{+}$RNA. Five micrograms of RNA and $1 \mu \mathrm{g}$ of primer were heated at $85^{\circ} \mathrm{C}$ for $15 \mathrm{~min}$ in $50 \mathrm{~mm}$ Tris (pH7.6), $60 \mathrm{mM}$ $\mathrm{KCl}, 10 \mathrm{mM} \mathrm{MgCl}, 1 \mathrm{mM}$ DTT, and $1 \mathrm{~mm}$ dNTPs. Reactions were then moved to $42^{\circ} \mathrm{C}$ for $15 \mathrm{~min}, 10$ units of AMV reverse transcriptase was added, and incubation continued at $42^{\circ} \mathrm{C}$ for 2 hr. The resulting cDNA was used as a template in a $100 \mu l$ PCR reaction containing $1 \times$ GeneAmp PCR buffer and $0.5 \mu$ of Taq DNA polymerase (Perkin-Elmer Cetus), $0.2 \mathrm{mM}$ dNTPs, and 1 $\mu \mathrm{M}$ T13rev and T25A (a degenerate oligonucleotide deduced from amino acids 7-12 of peptide 1T25). PCR conditions were at $94^{\circ} \mathrm{C}$ for $1 \mathrm{~min}$, hybridization for $2 \mathrm{~min}$ at varying temperatures, and extension at $72^{\circ} \mathrm{C}$ for $2 \mathrm{~min}$. For 5 cycles of the threetemperature PCR, hybridization was at $48^{\circ} \mathrm{C}$, for 4 cycles it was at $50^{\circ} \mathrm{C}$, and for 25 cycles it was at $60^{\circ} \mathrm{C}$. This resulted in a product of 200 nucleotides, which was subcloned, sequenced, and used to screen a human fetal brain cDNA library as in Zamore et al. (1992). Multiple clones were isolated, purified, and subcloned into plasmid vectors following standard protocols (Sambrook et al. 1989). Sequence analysis was carried out on exonuclease III deletion subclones (Henikoff 1984) or by using primers designed from new sequence. Sequence was obtained both manually using dideoxy terminators and on an Applied Biosystems model 370A automated DNA sequencer using Taq or Sequenase DNA polymerase on double-stranded templates. Sequences were analyzed using the University of Wisconsin GCG software as well as the BLAST program (Altschul et al. 1990).

\section{Antibodies, immunoprecipitations, Western blots, and immunodepletion}

Antibodies against PTB were as described (Patton et al. 1991). Antibodies against PSF were prepared against peptides 1T25 and 1 T13 after coupling to BSA with glutaraldehyde following Harlow and Lane (1988). Antibodies against pETPSF were prepared by injection of purified bacterially produced protein. $\mathrm{mAb}$ 24.1D5 was as described (Gower et al. 1989). Western blots and immunoprecipitation of ${ }^{35} \mathrm{~S}$-labeled HeLa cell extracts were as in Patton et al. (1991), except that cells were lysed in RIPA buffer $(150 \mathrm{~mm} \mathrm{NaCl}, 1 \% \mathrm{NP}-40,0.5 \%$ sodium deoxycholate, $0.1 \%$ SDS, $50 \mathrm{~mm}$ Tris at $\mathrm{pH} 7.5$ (Harlow and Lane 1988). Immunoprecipitation of ${ }^{35} \mathrm{~S}$-labeled in vitro-translated PTB and PSF was performed by incubation of lysate translations with antibodies for $1 \mathrm{hr}$ at $4^{\circ} \mathrm{C}$, followed by the addition of protein A-Sepharose for an additional hour at $4^{\circ} \mathrm{C}$. Immune complexes were washed with RIPA buffer before separation on $9 \%$ Laemmli gels (Laemmli 1970).

For affinity purification of anti-peptide antibodies, T25 and T13 peptides were dissovled in methanol and coupled to AffiGel 10 beads for $4 \mathrm{hr}$ at $4^{\circ} \mathrm{C}$. The beads were washed once with methanol followed by successive washes between $0.1 \mathrm{NaHCO}_{3}$, $0.5 \mathrm{M} \mathrm{NaCl}$ ( $\mathrm{pH} \mathrm{8.3)}$ ), and $0.1 \mathrm{M} \mathrm{NaOAc}$, and $0.5 \mathrm{M} \mathrm{NaCl}$ (pH 4.0). Beads were then washed and equilibrated in $10 \mathrm{mM}$ Tris $1 \mathrm{pH}$ 8.0). For affinity purification of IgG, sera were diluted $1: 10$ in $10 \mathrm{~mm}$ Tris (pH 8.0), followed by applicaton to the column. Sera were applied through three passages followed by washing with 10 column volumes of $10 \mathrm{mM}$ Tris $(\mathrm{pH} 8.0)$ and 10 column volumes of $100 \mathrm{~mm}$ Tris ( $\mathrm{pH} 8.0$ ). Antibodies were eluted with five column volumes of $0.1 \mathrm{M}$ glycine $(\mathrm{pH} 3.0)$, followed by five column volumes of $0.1 \mathrm{M}$ triethylamine $(\mathrm{pH} 10.5)$. Peak fractions were pooled and dialyzed against PBS.

Affinity purification of anti-pETPSF antibodies (113) was performed by passage of sera over Ni-NTA beads to which bacterial pETPSF was bound. pETPSF cultures were induced as described above and harvested under nondenaturing conditions following the manufacturer's instructions (Qiagen). Protein-bound beads were washed with 10 column volumes of $0.1 \mathrm{M}$ triethylamine $(\mathrm{pH} \mathrm{10.5)}$ after verifying that the fusion protein did not elute under these conditions. The beads were then equilibrated in 10 $\mathrm{mM}$ Tris ( $\mathrm{pH} 8.0)$, and sera diluted $1: 10$ in the same buffer were applied to the column and passaged three times. The column was washed as described above with high and low Tris concentrations followed by elution of antibodies with $0.1 \mathrm{M}$ of triethylamine (TEA) (pH 10.5). Eluted IgG was either dialyzed against PBS or concentrated with protein A-Sepharose beads.

An anti-PSF affinity column was prepared by coupling IgG to Affi-10 resin (Bio-Rad). Briefly, IgG from both anti-T25 and anti- 
T13 antibodies was coupled to Affi-10 resin in $0.1 \mathrm{M} \mathrm{NaHCO}_{3}$, $0.5 \mathrm{M} \mathrm{NaCl}(\mathrm{pH} 8.3)$ for $4 \mathrm{hr}$ at $4^{\circ} \mathrm{C}$. Coupled beads were blocked in $100 \mathrm{~mm}$ ethanolamine for $16 \mathrm{hr}$ at $4^{\circ} \mathrm{C}$, after which the beads were washed and equilibrated in nuclear extract dialysis buffer. A final concentration of $\sim 22 \mathrm{mg}$ of $\mathrm{IgG} / \mathrm{ml}$ of resin was achieved. Nuclear extracts were depleted of PSF by passage of extract over this column three times at $4^{\circ} \mathrm{C}$.

\section{Protein-binding assays}

Western transfers onto PVDF menbrane were performed as in Patton et al. (1991). Filters were probed with labeled proteins following Zhang et al. (1992). Briefly, membranes were blocked for $2 \mathrm{hr}$ at room temperature in $20 \mathrm{mM}$ Tris $|\mathrm{pH} 8| 20 \%$ glycerol, $1 \mathrm{M} \mathrm{KCl}, 0.2 \mathrm{~mm}$ EDTA, 5\% BSA, 0.1\% Tween 20, and $1 \mathrm{~mm}$ DTT. Binding was carried out in $40 \mathrm{ml}$ of the same buffer with $2.5 \times 10^{5} \mathrm{cpm}^{35} \mathrm{~S}$-labeled in vitro-translated PSF (clone F), overnight with rocking at room temperature. The membranes were washed five times for $10 \mathrm{~min}$ in the same buffer, allowed to dry at room temperature, and exposed to Kodak XAR5 film.

For resin-binding assays, the various GST fusion proteins were diluted $1: 10$ after overnight growth and kept at $37^{\circ} \mathrm{C}$ for $3 \mathrm{hr}$ before induction with $0.5 \mathrm{~mm}$ IPTG for $3 \mathrm{hr}$. Cultures were harvested as in Lin and Green (1991). In vitro-translated proteins were incubated with resin-bound proteins for $2 \mathrm{hr}$ at $4^{\circ} \mathrm{C}$ in $20 \mathrm{~mm}$ Tris (pH 8), $250 \mathrm{~mm} \mathrm{NaCl}, 1 \mathrm{~mm}$ EDTA, and 0.5\% NP-40. Beads were then washed five times in the same buffer before boiling and electrophoresis. In vitro translations were performed using rabbit reticulocyte lysates from Promega.

\section{Acknowledgments}

We thank Drs. Frank Walsh, Ann Beyer, and Tom Maniatis for providing antibodies and Robin Reed for communicating results before publication. We also thank Emily Fernandes, Maria-Dolores Chiara, Roger McCarrick and Tom O'Keeffe for DNA sequencing. Thanks also go to Massimo Buvoli for U5 snRNP purification and to Maria-Dolores Chiara for the MC-9 clone.

The publication costs of this article were defrayed in part by payment of page charges. This article must therefore be hereby marked "advertisement" in accordance with 18 USC section 1734 solely to indicate this fact.

\section{References}

Adam, S.A., T. Nakagawa, M. Swanson, T.A. Woodruff, and G. Dreyfuss. 1986. mRNA polyadenylate-binding protein: Gene isolation and sequencing and identification of ribonucleoprotein consensus sequence. Mol. Cell. Biol. 6: 2932-2943.

Altschul, S.F., W. Gish, W. Miller, E.W. Myers, and D.J. Lipman. 1990. Basic local alignment search tool. I. Mol. Biol. 215: 403-410.

Ast, G., D. Goldblatt, D. Offen, J. Sperling, and R. Sperling. 1991. A novel splicing factor is an integral component of the 200S large nuclear ribonucleoprotein (lnRNP) particles. EMBO I. 10: 425-432.

Bandziulis, R.J., M.S. Swanson, and G. Dreyfuss. 1989. RNAbinding proteins as developmental regulators. Genes \& Dev. 3: $431-437$.

Behrens, S.-E. and R. Lührmann. 1991. Immunoaffinity purification of a [U4/U6.U5] tri-snRNP from human cells. Genes \& Dev. 5: 1439-1452.

Bennett, M., S. Michaud, J. Kingston, and R. Reed. 1992a. Protein components specifically associated with prespliceosome and spliceosome complexes. Genes \& Dev. 6: 1986-
2000.

Bennett, M., S. Piñol-Roma, D. Staknis, G. Dreyfuss, and R. Reed. 1992b. Differential binding of heterogeneous nuclear ribonucleoproteins to mRNA precursors prior to spliceosome assembly in vitro. Mol. Cell. Biol. 12: 3165-3175.

Ben-David, Y., M. Rosa Bani, B. Chabot, A. De Koven, and A. Bernstein. 1992. Retroviral insertions downstream of the heterogeneous nuclear ribonucleoprotein A1 gene in erythroleukemia cells: Evidence that Al is not essential for cell growth. Mol. Cell. Biol. 12: 4449-4455.

Beyer, A.L., M.E. Christensen, B.W. Walker, and W.M. LeStourgeon. 1977. Identification and characterization of the packaging proteins of core 40S hnRNP particles. Cell 11: 127138.

Bindereif, A. and M.R. Green. 1986. Ribonucleoprotein complex formation during pre-mRNA splicing in vitro. Mol. Cell. Biol. 6: 2582-2592.

Calnan, B.J., B. Tidor, S. Biancalana, D. Hudson, and A. Frankel. 1991. Arginine-mediated RNA recognition: The arginine fork. Science 252: 1167-1170.

Choi, Y.D., P.J. Grabowski, P.A. Sharp, and G. Dreyfuss. 1986. Heterogeneous nuclear ribonucleoproteins: Role in RNA splicing. Science 231: 1534-1539.

Courey, A.J. and R. Tjian. 1988. Analysis of $\mathrm{Spl}$ in vivo reveals multiple transcriptional domains, including a novel glutamine-rich activation motif. Cell 55: 887-898.

Datta, B. and A.M. Weiner. 1991 Genetic evidence for base pairing between $\mathrm{U} 2$ and $\mathrm{U} 6$ snRNA in mammalian mRNA splicing. Nature 352: 821-824.

Delannoy, P. and M.H. Caruthers. 1991. Detection and characterization of a factor which rescues spliceosome asembly from a heat-inactivated HeLa cell nuclear extract. Mol. Cell. Biol. 11: 3425-3431.

Frendeway, D. and W. Keller. 1985. The stepwise assembly of a pre-mRNA splicing complex requires U-snRNPs and specific intron sequences. Cell 42: 355-367.

Frohman, M.A. 1990. RACE: Rapid amplification of cDNA Ends. In PCR protocols (ed. M.A. Innis, D.H. Gelfand, J.J. Sninsky, and T.J. Whitel, pp. 28-38. Academic Press, Boston, MA.

Fu, X.-D. and T. Maniatis. 1990. Factor required for mammalian spliceosome assembly is localized to discrete regions in the nucleus. Nature 343: 437-441.

- 1992. Isolation of complementary DNA that encodes the mammalian splicing factor SC35. Science 256: 535-538.

Garcia-Blanco, M.A., S.F. Jamison, and P.A. Sharp. 1989. Identification and purification of a 62,000-dalton protein that binds specifically to the polypyrimidine tract of introns. Genes \& Dev. 3: 1874-1886.

Ge, H. and J.L. Manley. 1990. A protein factor, ASF, controls cell-specific alternative splicing of SV40 early pre-mRNA in vitro. Cell 62: 25-34.

- 1991. Primary structure of the human splicing factor ASF reveals similarities with Drosophila regulators. Cell 66: 373-382.

Gerke, V. and J.A. Steitz. 1986. A protein associated with small nuclear ribonucleoprotein particles recognizes the $3^{\prime}$ splice site of premessenger RNA. Cell 47: 973-984.

Gil, A., P.A. Sharp, S.F. Jamison, and M.A. Garcia-Blanco. 1991. Characterization of cDNAs encoding the polypyrimidine tract-binding protein. Genes \& Dev. 5: 1224-1236.

Gower, H.J., S.E. Moore, G. Dickson, V.L. Elsom. R. Nayak, and F.S. Walsh. 1989. Cloning and characterization of a myoblast cell-surface antigen defined by $24.1 \mathrm{D} 5$ monoclonal antibody. Development 105: 723-731.

Green, M.R. 1991. Biochemical mechanisms of constitutive and regulated pre-mRNA splicing. Annu. Rev. Cell Biol. 7: 559- 
599.

Guthrie, C. 1991. Messenger RNA splicing in yeast: Clues to why the spliceosome is a ribonucleoprotein. Science 253: 157-163.

Harlow, E. and D. Lane. 1988. Antibodies: A laboratory manual. Cold Spring Harbor Laboratory, Cold Spring Harbor, New York.

Harper, J.E. and J.L. Manley. 1991. A novel protein factor is required for use of distal alternative $5^{\prime}$ splice sites in vitro. Mol. Cell. Biol. 11: 5945-5953.

Heinrichs, V., M. Bach, G. Winkelmann, and R. Lührmann. 1990. U1-specific protein C needed for efficient complex formation of Ul snRNP with a 5' splice site. Science 247: 6972.

Henikoff, S. 1984. Unidirectional digestion with exonuclease III creates targeted breakpoints for DNA sequencing. Gene 28: 351-359.

Jamison, S.F., A. Crow, and M.A. Garcia-Blanco. 1992. The spliceosome assembly pathway in mammalian extracts. Mol. Cell. Biol. 12: 4279-4287.

Kenan, D.J., C.C. Query, and J.D. Keene. 1991. RNA recognition: Towards identifying determinants of specificity. Trends Biochem. Sci. 16: 214-220.

Kiledjian, M. and G. Dreyfuss. 1992. Primary structure and binding specificity of the hnRNP $U$ protein: Binding RNA through RGG box. EMBO I. 11: 2655-2664.

Konarska, M.M. and P.A. Sharp. 1986. Electrophoretic separation of complexes involved in the splicing of precursors to mRNAs. Cell 46: 845-855.

Krainer, A.R. and T. Maniatis. 1985. Multiple factors including the small nuclear ribonucleoproteins $\mathrm{U} 1$ and $\mathrm{U} 2$ are necessary for pre-mRNA splicing in vitro. Cell 42: 725-736.

- 1988. RNA splicing. In Frontiers in molecular biology: Transcription and splicing (ed. B.D. Hames and D.M. Glover|, pp.131-206. IRL Press, Washington, D.C.

Krainer, A.R., G.C. Conway, and D. Kozak. 1990a. Purification and characterization of pre-mRNA splicing factor SF2 from HeLa cells. Genes \& Dev. 4: 1158-1171.

. 1990b. The essential pre-mRNA splicing factor SF2 influences 5 ' splice site selection by activating proximal sites. Cell 62: 35-42.

Krainer, A.R., A. Mayeda, D. Kozak, and G. Binns. 1991. Functional expression of cloned human splicing factor SF2: Homology to RNA-binding proteins, U1 70K, and Drosophila splicing regulators. Cell 66: 383-394.

Kramer, A. 1992. Purification of splicing factor SF1, a heat-stable protein that functions in the assembly of a presplicing complex. Mol. Cell. Biol. 12: 4545-4552.

Kramer, A. and U. Utans. 1991. Three protein factors (SF1, SF3, and $\mathrm{U} 2 \mathrm{AF}$ ) function in the pre-splicing complex formation in addition to snRNPs. EMBO $/$. 10: 1503-1509.

Kramer, A., M. Frick, and W. Keller. 1987. Separation of multiple components of HeLa cell nuclear extracts required for pre-messenger RNA splicing. I. Biol. Chem. 262: 1763017640.

Laemmli, U.K. 1970. Cleavage of structural proteins during the assembly of the head of bacteriophage T4. Nature 227: 680685.

Li, H. and P.M. Bingham. 1991. Arginine/serine-rich domains of the $s u\left(w^{a}\right)$ and tra RNA processing regulators target proteins to a subnuclear compartment implicated in splicing. Cell 67: $335-342$.

Lin, Y.-S. and M.R. Green. 1991. Mechanism of action of an acidic transcriptional activator in vitro. Cell 64: 971-981.

Lührmann, R. 1988. snRNP proteins. In Small nuclear ribonucleoprotein particles (ed. M.L. Birnstiel), pp. 71-99. Springer-
Verlag, Berlin, Germany.

Mayeda, A. and A.R. Krainer. 1992. Regulation of alternative pre-mRNA splicing by hnRNP A1 and splicing factor SF2. Cell 68: 365-375.

Mayeda, A., K. Tatei, H. Kitayama, K. Takemura, and Y. Ohshima. 1986. Three distinct activities possibly involved in mRNA splicing are found in a nuclear fraction lacking $U 1$ and U2 RNA. Nucleic Acids Res. 14: 3045-3057.

Mount, S.M. 1982. A catalogue of splice junction sequences. Nucleic Acids Res. 10: 459-472.

Mullen, M.P., C.W.J. Smith, J.G. Patton, and B. Nadal-Ginard. 1991. $\alpha$-Tropomyosin mutually exclusive exon selection: Competition between branchpoint/polypyrimidine tracts determines exon choice. Genes \& Dev. 5: 642-655.

Muller, M.M., S. Ruppert, W. Schaffner, and P. Matthias. 1988. A cloned octamer transcription factor stimulates transcription from lymphoid-specific promoters in non-B cells. $\mathrm{Na}$ ture 336: 544-551.

Newman, A.J. and C. Norman. 1992. U5 snRNA interacts with exon sequences at $5^{\prime}$ and $3^{\prime}$ splice sites. Cell 68: 743-754.

Ohshima, Y. and Y. Gotoh. 1987. Signals for the selection of a splice site in pre-mRNA. I. Mol. Biol. 195: 247-259.

Patton, J.G., S.A. Mayer, P. Tempst, and B. Nadal-Ginard. 1991. Characterization and molecular cloning of polypyrimidine tract-binding protein: A component of a complex necessary for pre-mRNA splicing. Genes \& Dev. 5: 1237-1251.

Piñol-Roma, S., M.S. Swanson, J.G. Gall, and G. Dreyfuss. 1989. A novel heterogeneous nuclear RNP protein with a unique distribution on nascent transcripts. I. Cell. Biol. 109: 25752587.

Pruzan, R., H. Furneaux, P. Lassota, G.Y. Hong, and J. Hurwitz. 1990. Assemblage of the prespliceosome complex with separated fractions isolated from HeLa cells. J. Biol. Chem. 265: 2804-2813.

Reed, R. 1990. Protein composition of mammalian spliceosomes assembled in vitro. Proc. Natl. Acad. Sci. 87: 80318035.

Reed, R. and T. Maniatis. 1985. Intron sequences involved in lariat formation during pre-mRNA splicing. Cell 41: 95-105.

Reich, C.I., R.W. VanHoy, G.L. Porter, and J. Wise. 1992. Mutations at the $3^{\prime}$ splice site can be suppressed by compensatory base changes in U1 snRNA in fission yeast. Cell 69: 1159-1169.

Rokeach, L.A., M. Jannatipour, J.A. Haselby, and S.A. Hoch. 1989. Primary structure of a human small nuclear ribonucleoprotein polypeptide as deduced by cDNA analysis. I. Biol. Chem. 264: 5024-5030.

Ruby, S.W. and J. Abelson. 1991. Pre-mRNA splicing in yeast. Trends Genet. 7: 79-85.

Ruskin, B. and M.R. Green. 1985. Role of the $3^{\prime}$ splice site consensus sequence in mammalian pre-mRNA splicing. $\mathrm{Na}$ ture 317: 732-734.

Ruskin, B., P.D. Zamore, and M.R. Green. 1988. A factor, U2AF, is required for U2 snRNP binding and splicing complex assembly. Cell 52: 207-219.

Sachs, A.B., M.W. Bond, and R.D. Kornberg. 1986. A single gene from yeast fro both nuclear and cytoplasmic polyadenylatebinding proteins: Domain structure and expression. Cell 45: $827-835$.

Sambrook, J., E.F. Fritsch, and T. Maniatis. 1989. In Molecular cloning: A laboratory manual, 2nd ed. Cold Spring Harbor Laboratory Press, Cold Spring Harbor, New York.

Santoro, C., N. Mermod, P.C. Andrews, and R. Tjian. 1988. A family of human CCAAT-box-binding proteins active in transcription and DNA replication: Cloning and expression of multiple cDNAs. Nature 334: 218-224. 
Sharp, P. 1987. Splicing of messenger RNA precursors. Science 235: 766-771.

Sillekens, P.T.G., W.J. Habets, R.P. Beijer, and W.J. van Venrooij. 1987. cDNA cloning of the human U1 snRNA-associated A protein: Extensive homology between U1 and U2 snRNP-specific proteins. EMBO I. 6: 3841-3848.

Sillekens, P.T.G., R.P. Beijer, W.J. Habets, and W.J. van Venrooij. 1988. Human U1 snRNP-specific C protein: Complete cDNA and protein sequence and identification of a multigene family in mammals. Nucleic Acids Res. 16: 8307-8328.

Smith, C.W.J. and B. Nadal-Ginard. 1989. Mutually exclusive splicing of $\alpha$-tropomyosin exons enforced by an unusual lariat branchpoint location; Implications for constitutive splicing. Cell 56: 749-758.

Smith, C.W.J., J.G. Patton, and B. Nadal-Ginard. 1989a. Alternative splicing in the control of gene expression. Annu. Rev. Gen. 23: 527-577.

Smith, C.W.J., E.B. Porro, J.G. Patton, and B. Nadal-Ginard. 1989b. Scanning from an independently specified branchpoint defines the $3^{\prime}$ splice site of mammalian introns. $\mathrm{Na}$ ture 342: 243-247.

Steitz, J.A. 1992. Splicing takes a holiday. Science 257: 888-889.

Steitz, J.A., D.L. Black, V. Gerke, K.A. Parker, A. Kramer, D. Frendeway, and W. Keller. 1988. Functions of the abundant U-snRNPs. In Small nuclear ribonucleoprotein particles (ed. M.L. Birnstiel), pp. 115-154. Springer-Verlag, Berlin, Germany.

Swanson, M.S. and G. Dreyfuss. 1988. RNA-binding specificity of hnRNP proteins: A subset bind to the $3^{\prime}$ end of introns. EMBO I. 7: 3519-3529.

Tanese, N., F. Pugh, and R. Tjian. 1991. Coactivators for a proline-rich activator purified from the multisubunit human TFIID complex. Genes \& Dev. 5: 2212-2224.

Tazi, J., C. Alibert, J. Temsamani, I. Reveillaud, G. Cathala, C. Brunel, and P. Jeanteur. 1986. A protein that specifically recognizes the $3^{\prime}$ splice site of mammalian pre-mRNA introns is associated with a small nuclear ribonucleoprotein. Cell 47: 755-766.

Utans, U. and A. Kramer. 1990. Splicing factor SF4 is dispensable for the assembly of a functional splicing complex and participates in the subsequent steps of the splicing reaction. EMBO J. 9: 4119-4126.

Utans, U., S.-E. Behrens, R. Lührmann, R. Kole, and A. Kramer. 1992. A splicing factor that is inactivated during in vivo heat shock is functionally equivalent to the U4/U6/U5 triple snRNP-specific proteins. Genes \& Dev. 6: 631-641.

Wassarman, D.A. and J.A. Steitz. 1992. Interactions of small nuclear RNAs with precursor messenger RNA during in vitro splicing. Science 257: 1918-1925.

Williams, T., A. Admon, B. Luscher, and R. Tjian. 1988. Cloning and expression of AP-2, a cell type specific transcription factor that activates inducible enhancer elements. Genes \& Dev. 2: 1557-1569.

Wu, J. and J.L. Manley. 1991. Base pairing between U2 and U6 snRNAs is necessary for splicing of a mammalian premRNA. Nature 352: 818-824.

Zahler, A.M., W.S. Lane, J.A. Stolk, and M.B. Roth. 1992. SR proteins: A conserved family of pre-mRNA splicing factors. Genes \& Dev. 6: 837-847.

Zamore, P.D. and M.R. Green. 1989. Identification, purification, and biochemical characterization of U2 small nuclear ribonucleoprotein auxiliary factor. Proc. Natl. Acad. Sci. 86: 9243-9247.

- 1991. Biochemical characterization of U2 snRNP auxiliary factor: An essential pre-mRNA splicing factor with a novel intranuclear distribution. EMBO $/$. 10: 207-214.
Zamore, P.D., J.G. Patton, and M.R. Green. 1992. Cloning and domain structure of the mammalian splicing factor U2AF. Nature 355: 609-614.

Zhang, M., P.D. Zamore, M. Carmo-Fonseca, A.I. Lamond, and M.R. Green. 1992. Cloning and intracellular localization of the U2 small nuclear ribonucleoprotein auxiliary factor small subunit. Proc. Natl. Acad. Sci. 89: 8769-8773.

Zillman, M., S.D. Rose, and S.M. Berget. 1987. U1 small nuclear ribonucleoproteins are required early during spliceosome assembly. Mol. Cell. Biol. 7: 2877-2883.

Zillman, M., M.L. Zapp, and S.M. Berget. 1988. Gel electrophoretic isolation of splicing complexes containing Ul small nuclear ribonucleoprotein particles. Mol. Cell. Biol. 8: 814 821. 


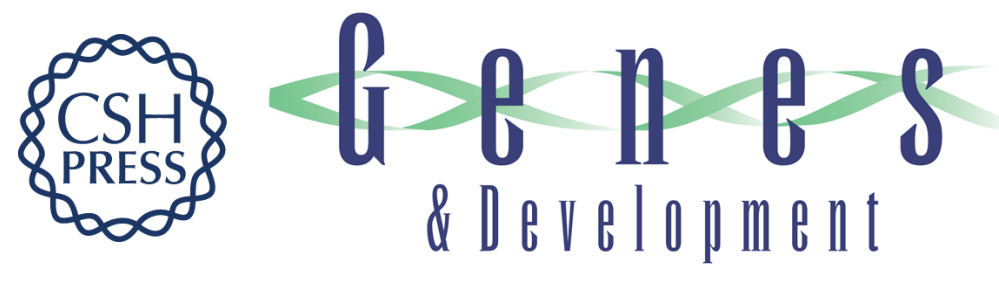

\section{Cloning and characterization of PSF, a novel pre-mRNA splicing factor.}

J G Patton, E B Porro, J Galceran, et al.

Genes Dev. 1993, 7:

Access the most recent version at doi:10.1101/gad.7.3.393

References This article cites 84 articles, 38 of which can be accessed free at:

http://genesdev.cshlp.org/content/7/3/393.full.html\#ref-list-1

\section{License}

Email Alerting

Service

Receive free email alerts when new articles cite this article - sign up in the box at the top right corner of the article or click here.

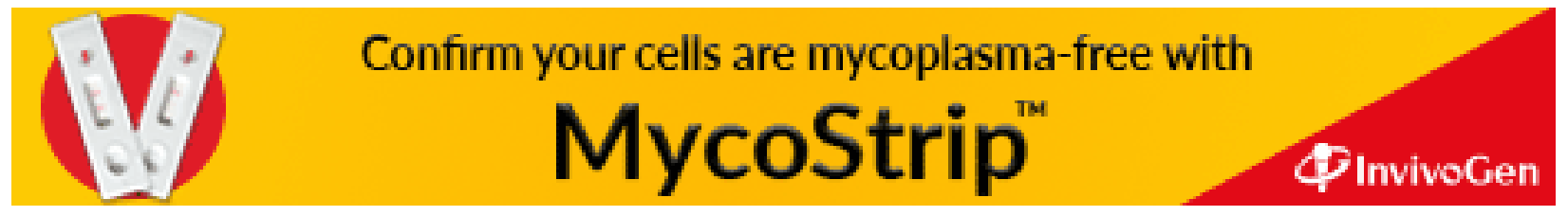

